\title{
Evaluation of ecosystem services provided by farmed and wild seaweeds
}

Marine macroalgae provide a variety of ecosystem services in the environmental, social and economic spheres. This study presents a qualitative assessment of the ecosystem services offered by marine macroalgae (cultivated and natural populations). Furthermore, it provides a better understanding of the benefits of macroalgae cultivated in a case study (Gracilaria birdiae) in a tropical area in Brazil. For this, a literature review was carried out using articles available on the internet (Web of Science, Science Direct, Scopus, Scielo and Google Scholar) published between 2009 and 2020, which addressed the ecosystem services associated with macroalgae. A total of 1,428 articles were analyzed, of which 163 reported some type of ecosystem service. The most registered service was regulation (30.1\%), followed by provision ( $28.4 \%)$, support $(28.0 \%)$ and cultural $(13.5 \%)$. In the case study, 12 services were identified, five of which belonged to support, three to cultural, two to provision and two to regulation. Thus, both cultivated macroalgae and natural populations offer diverse ecosystem services that contribute to environmental improvement and play a positive role in the preservation and conservation of the environment and human well-being. In addition, the ecosystem services provided by macroalgae are fully aligned with several Sustainable Development Goals, especially SDGs 2, 3, 5, 8, 10, 12, 13 and 14, which encompass the three pillars of sustainability (environmental, social and economic).

Keywords: Ecosystem services; Macroalgae; Macroalgae cultivation; Natural populations; would grace.

\section{Avaliação dos serviços ecossistêmicos fornecidos por algas cultivadas e selvagens}

\begin{abstract}
As macroalgas marinhas fornecem uma variedade de serviços ecossistêmicos nas esferas ambiental, social e econômica. Este estudo apresenta uma avaliação qualitativa dos serviços ecossistêmicos oferecidos pelas macroalgas marinhas (cultivadas e de populações naturais). Além disso, fornece um melhor entendimento dos benefícios das macroalgas cultivadas num caso de estudo (Gracilaria birdiae) numa área tropical no Brasil. Para isso, uma revisão bibliográfica foi realizada usando artigos disponíveis na internet (Web of Science, Science Direct, Scopus, Scielo e Google Scholar) publicados entre 2009 e 2020, os quais abordaram os serviços ecossistêmicos associados às macroalgas. Um total de 1.428 artigos foi analisado, dos quais 163 reportaram algum tipo de serviço ecossistêmico. O serviç̧o mais registrado foi o de regulação $(30,1 \%)$, seguido por provisão $(28,4 \%)$, suporte $(28,0 \%)$ e cultural $(13,5 \%)$. No caso de estudo, 12 serviços foram identificados, cinco dos quais pertenceram ao de suporte, três ao cultural, dois ao de provisão e dois ao de regulação. Assim, tanto as macroalgas cultivadas quanto as populações naturais oferecem diversos serviços ecossistêmicos que contribuem para o melhoramento ambiental e têm papel positivo na preservação e conservação do meio ambiente e do bem-estar humano. Além disso, os serviços ecossistêmicos fornecidos pelas macroalgas estão totalmente alinhados com diversos Objetivos de Desenvolvimento Sustentável, sobretudo aos ODS 2, 3, 5, 8, 10,12, 13 e 14, os quais englobam os três pilares da sustentabilidade (ambiental, social e econômico).
\end{abstract}

Palavras-chave: Serviços ecossistêmicos; Macroalgas; Cultivo de macroalgas; Populações naturais; Gracilaria.

Topic: Desenvolvimento, Sustentabilidade e Meio Ambiente

Reviewed anonymously in the process of blind peer.

Ana Beatriz Gomes Ferreira (DD

Universidade Federal do Rio Grande do Norte, Brasil http://lattes.cnpq.br/3428643449624579

https://orcid.org/0000-0003-1532-2320

beatriz_biologia@hotmail.com

Marcella Araújo do Amaral Carneiro (iD

Universidade Federal do Rio Grande do Norte, Brasil

http://lattes.cnpq.br/2397478558863939

http://orcid.org/0000-0002-9823-3384

marcellamaralcarneiro@gmail.com

Felipe de Oliveira Fernandes (iD

Universidade Federal do Rio Grande do Norte, Brasil

http://lattes.cnpq.br/5612264477573380

https://orcid.org/0000-0002-9530-5995

fernandesfo@outlook.com
Received: 06/06/2021

Approved: 28/06/2021
Eliane Marinho Soriano (iD)

Universidade Federal do Rio Grande do Norte, Brasil

http://lattes.cnpq.br/2017823516741199

https://orcid.org/0000-0001-6736-3795

eliane@ufrnet.br
Referencing this:

FERREIRA, A. B. G.; CARNEIRO, M. A. A.; FERNANDES, F. O.; SORIANO, E. M.. Evaluation of ecosystem services provided by farmed and wild seaweeds. Revista Ibero Americana de Ciências Ambientais, v.12, n.6, p.499-511, 2021. DOI: http://doi.org/10.6008/CBPC2179$\underline{6858.2021 .006 .0041}$ 


\section{INTRODUCTION}

Fast environmental changes threaten the proper functioning of marine ecosystems. The increase in ocean temperature, habitat destruction and pollution, which most of coastal areas has been degraded due to anthropogenic action, influences species distribution, community structure and ecosystem functions (SMALE et al., 2013). These impacts may compromise the ecosystem ability to provide benefits to society, which are known as ecosystem services (SUNDAY et al., 2012). The structure of ecosystem services includes ecological, economic and social sectors and is divided into four categories: regulation (e.g., geochemical cycles), support (e.g., habitat), provision (e.g., food) and cultural (e.g., scientific research) (GROOT et al., 2002).

Marine and coastal ecosystems are among the most productive in the world, providing many social and economic benefits for people. Around the world, coastal areas are dominated by structurally complex habitats, formed by seaweed beds. When seaweed assemblages are established in shallow areas, they lead to considerable changes in the ecosystem structure and function, many of which can generate goods and services (TROELL et al., 2005). These seaweed beds are very productive and offer several ecosystem services (SMALE et al., 2013; SOARES et al., 2018; SFRISO et al., 2020), such as food, shelter and nursery for a variety of ecologically and economically important species (THOMPSON et al., 2002). In addition, these services enable positive externalities such as nutrient absorption, carbon sequestration and increased biodiversity (HASSELSTRÖM et al., 2018).

Seaweed farming also provides ecosystem services like natural beds. From an economic point of view, algal biomass can be used in several ways, including as food, drug development, feed ingredients and biofuels (DELANEY et al., 2016; BUSCHMANN et al., 2017). Furthermore, studies have shown that cultivation contributes to improving water quality (oxygen production), removing nutrients ( $\mathrm{N}$ and $\mathrm{P}$ ) and sequestering $\mathrm{CO}_{2}$. In Brazil, experiments of cultivating seaweed have been carried out in the Northeast, Southeast and South regions. However, despite a promising outlook, this activity is still in an initial stage. Currently, smallscale cultivation of a native species (Gracilaria birdiae) has been developed by Association of Seaweed Farming (AMAR). This seaweed farm has been seen as a complementary source of income to the women who carry out this activity and consequently improving their quality of life (MARINHO-SORIANO, 2017).

Recently, the ecosystem services have been widely used to assess potential environmental improvements in mariculture (GENTRY et al., 2020). Considering that most coastal areas has been degraded by anthropogenic action such as habitat destruction, pollution and overfishing, the quantification of ecosystem services can serve as a strong incentive for the conservation of marine ecosystems (HALPERN et al., 2012).

This study aims to: (1) qualitatively evaluate the ecosystem services provided by seaweeds (natural beds and cultivation) available in accessible articles on the web and (2) identify the ecosystem services of cultivation (G. birdiae) through a case study in Northeast Brazil. 


\section{MATERIALS AND METHODS}

To identify ecosystem services offered by seaweeds, the classification scheme developed by The Economics of Ecosystems and Biodiversity working group Groot et al. (2010) was used, which provides qualitative tools and describes the relationship between ecosystem services and human well-being. A classification list for ecosystem services proposed by Groot et al. (2002) was also used.

Bibliographic research was performed using the terms "ecosystem services" and "seaweed". These words were intentionally selected in order to group the largest number of articles related to seaweed, accessible on the platforms Web of Science, Science Direct, Scopus, Scielo and Google Scholar. Only articles published between 2009 and 2020 were included in the bibliographic research.

In a second stage, the articles on ecosystem services provided by seaweeds were analyzed to create a word cloud to highlight the main ecosystem services of each function. The original texts were analyzed and separated to be compiled later into a continuous text and inserted in the online word cloud generator ${ }^{1}$.

A list was compiled of ecosystem services identified in the cultivation of the seaweed G. birdiae on Rio do Fogo beach $\left(05^{\circ} 16^{\prime} 22^{\prime \prime} \mathrm{S}-35^{\circ} 22^{\prime} 57^{\prime \prime} \mathrm{W}\right)$, in the tropical area, Northeast region of Brazil (Figure 1). This beach is a typical fishing village, characterized by great environmental diversity as well as diverse activities, especially extractivism. These communities live exclusively on exploiting aquatic organisms, either for personal consumption or commercialization. Seaweed harvesting in Brazilian Northeast (Rio do Fogo beach) is a traditional activity carried out by the local community. Seaweed harvesting is performed manually throughout the year in the shallow intertidal and subtidal zones (Figure 2a). For many years this activity was an important source of income for several fishing families from which they obtained their primary income. In the last decades, algal biomass has decreased considerably, leading many harvesters to return to artisanal fishing (MARINHO-SORIANO, 2017).

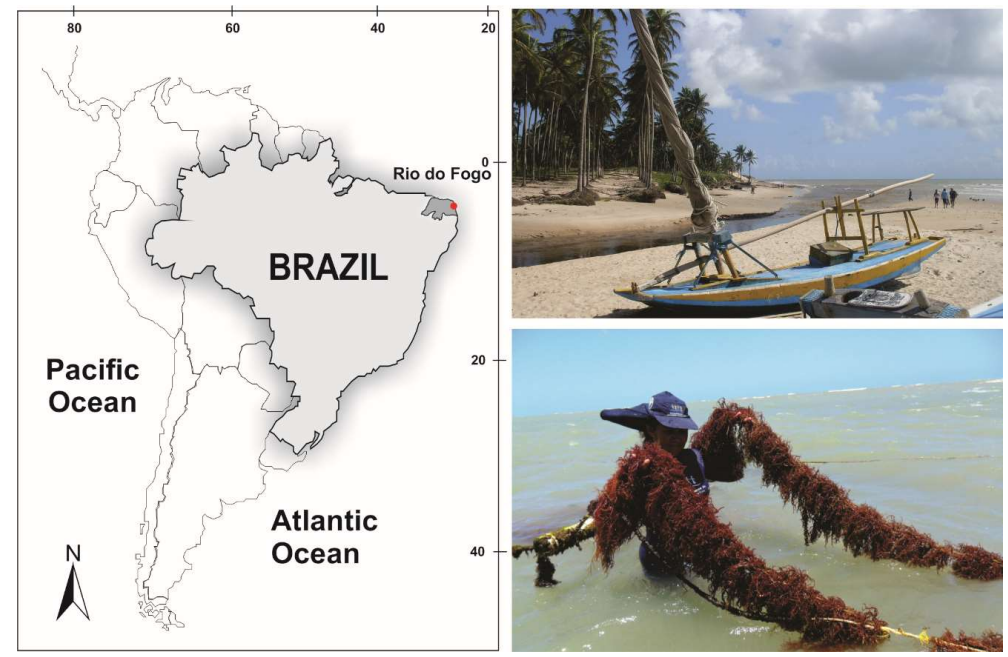

Figure 1: Cultivation area in the coast of Northeast region of Brazil.

In 2006 the seaweed cultivation of Gracilaria birdiae was implemented, using the technique of vegetative propagation. Cultivation is carried out in suspended structures (floating rafts) located 150 meters

\footnotetext{
${ }^{1}$ http://www.wordclouds.com
} 
from the beach. The rafts are composed of PVC pipes, nylon ropes and tubular nets (similar to those used in mussel cultivation). The rafts measure approximately 50 meters in length and are subdivided into 10 modules of $5 \mathrm{~m} \times 5 \mathrm{~m}$ each (Figure $2 \mathrm{~b}$ ). Cultivation is carried out mainly by woman, who also harvest seaweeds from the natural beds.
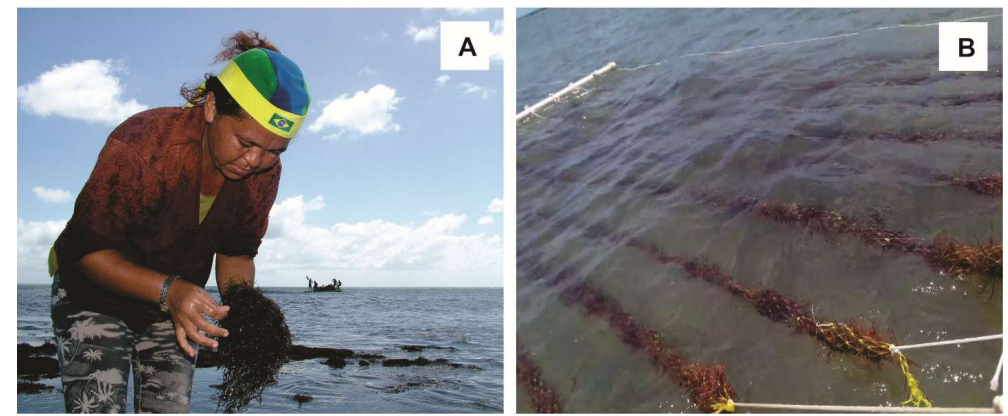

Figure 2: A) Harvest of seaweed G. birdiae from natural beds performed in the inter-tidal zone; B) Structure of the cultivation of seaweed G. birdiae used at Rio do Fogo beach.

\section{RESULTS AND DISCUSSION}

\section{Ecosystem services associated with seaweeds}

Seaweeds offer a variety of services and a wide range of benefits to human well-being. Through the bibliographic research on studies carried out around the world, it was possible to identify, classify and analyze the ecosystem services provided by seaweeds in each of the four categories defined by TEEB (GROOT et al., 2010).

In this study, 1,428 articles were analyzed, of which 163 reported some type of ecosystem service provided by seaweed related to the categories of provision, support, regulation and cultural., Geographically, most research on this subject was carried out in Europe (35.6\%), followed by Asia (24.5\%), South America (14.7\%), North America (10.4\%), Oceania (9.2\%), Africa (4.9\%) and Central America (0.7\%) (Figure 3).

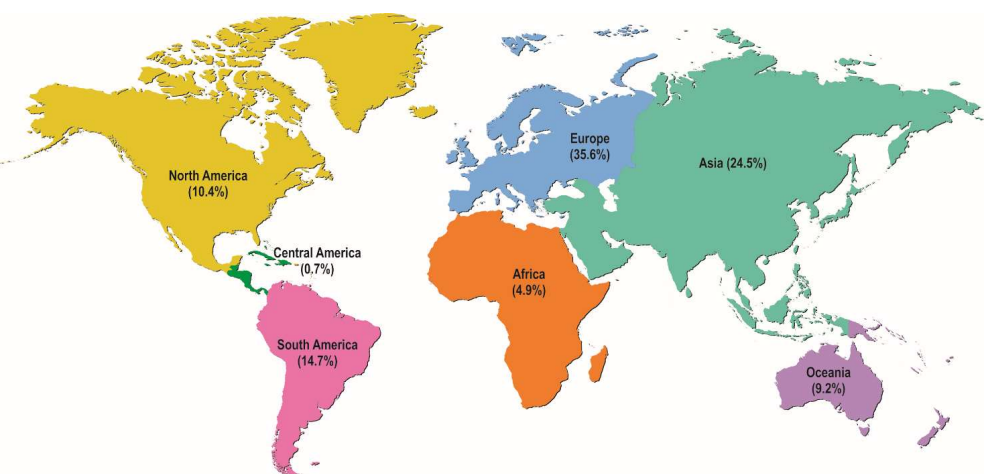

Figure 3: Geographic distribution of the research carried out on ecosystem services associated with seaweeds.

Table 1 shows 16 ecosystem services associated with seaweeds found in the bibliographic review. Of this total, three ecosystem services fall into the category of regulation, five in provision, four in support and four in cultural. The number of references on the subject is relative to the quantity of ecosystem services found in the consulted bibliography, being counted even if more than one service is identified in the same work. 
Table 1: Ecosystem services of wild and cultured seaweeds identified in the literature.

\begin{tabular}{lll}
\hline Category & Ecosystem Services & Subject References \\
\hline \multirow{3}{*}{ Regulation } & Bioremediation & $42(48.3 \%)$ \\
& Climate regulation & $39(44.8 \%)$ \\
& Sediment retention & $06(6.9 \%)$ \\
\hline \multirow{4}{*}{ Provision } & Raw material & $24(29.3 \%)$ \\
& Food production & $22(26.8 \%)$ \\
& Bioactives for pharmaceutical industry & $18(22.0 \%)$ \\
& Energy resources & $17(20.7 \%)$ \\
& Ornamental resources & $01(1.2 \%)$ \\
\hline \multirow{3}{*}{ Support } & Habitats & $46(56.8 \%)$ \\
& Maintenance of biological and genetic diversity & $14(17.3 \%)$ \\
& Primary Production & $12(14.8 \%)$ \\
& Food web dynamics & $09(11.1 \%)$ \\
\hline \multirow{3}{*}{ Cultural } & Generation of employment and income & $18(46.2 \%)$ \\
& Science and education & $10(25.6 \%)$ \\
& Cultural heritage & $06(15.4 \%)$ \\
& Recreation & $05(12.8 \%)$ \\
\hline
\end{tabular}

Regulating services presented the largest number of studies of the scientific articles consulted, corresponding to $30.1 \%$ and totaling 87 references. Regarding these services, $48.3 \%$ addressed the bioremediation capacity of seaweeds. The increase in marine pollution and eutrophication processes has contributed to the rise of research using seaweed in removing nutrients (NARDELLI et al., 2019). Most of these studies refers to integrated and multitrophic cultivation (MARINHO-SORIANO et al., 2009a; MARINHOSORIANO et al., 2009b; MARINHO-SORIANO 2013; KANG et al., 2014; ROBERTS et al., 2015; AUGYTE et al., 2017; GAO et al., 2018). Related to the bioremediation capacity, Wu et al. (2018) reported that Pyropia yezoensis can remove excess nutrients from coastal waters and can be used as a nutrient recycling tool in eutrophic waters.

Studies linked to climate regulation represented $44.8 \%$ and examined the role of seaweeds as a mitigator of environmental changes (SONDAK et al., 2017). These articles discussed the use of seaweed as $\mathrm{CO}_{2}$ sequestrators, mainly in studies addressing climate change, air quality mitigation and climate regulation (CHUNG et al., 2017). Callaway et al. (2012) evaluated the consequences of climate change on mariculture activity in the United Kingdom and Ireland, suggesting that rising sea temperature will negatively affect the seaweed farming in these locations. Furthermore, several works indicated that seaweed farming in open sea (Laminaria spp.) and multitrophic cultivation (Gracilaria spp.) have a great capacity to absorb $\mathrm{CO}_{2}$. In such cases, seaweed farming is considered as a natural carbon stock (KRAUSE-JENSEN et al., 2016; ARINA et al., 2020). This potential has a clear implication in carbon sequestration and regulation of ocean acidification, generating benefits in climate regulation (CHUNG et al., 2011; CHUNG et al., 2013; CHUNG et al., 2017; HAN et al., 2013; MONGIN et al., 2016).

The service of sediment retention was discussed in $6.9 \%$ of the studies analyzed. The suspended seaweed cultivations located close to the coast can reduce the energy flow of waves upon the coast, protecting it from possible erosion (HASSELSTRÖM et al., 2018).

The second most discussed category in the studies was provisioning services, corresponding to $28.4 \%$ of the literature consulted ( 82 references on the subject). Of this total, most of the studies addressed biomass production (29.3\%). This is mainly linked with obtaining raw material for the phycocolloid industry and the 
studies were carried out primarily on commercial farming (STÉVANT et al., 2017; MANTRI et al., 2017). The use of seaweeds for food production and as a source of bioactive compounds for the pharmaceutical industry represented $26.8 \%$ and $22.0 \%$ of the studies, respectively. These researches pointed out that seaweeds are rich in protein, pigments and carbohydrates and can be used as food, feed, fertilizer and nutraceutical products (PEREIRA et al., 2009; MARTINS et al., 2016; ASMAWATI et al., 2016; GAILLANDE et al., 2017; KIM et al., 2017).

The use of seaweeds as an energy source was discussed in $20.7 \%$ of the articles. Most of these studies reported that seaweeds had significant amounts of carbohydrates (hexose), which can be used for fermentation and ethanol production (GOH et al., 2010; FASAHATI et al., 2015). The results showed that seaweeds may be candidates to replace fossil fuels, reducing the vulnerability of this sector and providing sustainable energy. The least mentioned provisioning service was the use of seaweeds as ornamental sources, addressed only in $1.2 \%$ of the articles. This subject involved the use of seaweed as a decorative object and suggested the supply of raw material for use in souvenirs and bringing about socioeconomic benefits (HASSELSTRÖM et al., 2018).

Supporting services were examined in $\mathbf{2 8 . 0 \%}$ of the studies (mentioned 81 times). Habitat services and maintenance of biological and genetic diversity corresponded to $56.8 \%$ and $17.3 \%$ of the supporting services, respectively, referring mainly to seaweed natural beds, especially kelps (SMALE et al., 2013). About $14.8 \%$ of the studies indicated seaweed as the dominant primary producers in the coastal zone (KRAUSEJENSEN et al., 2016; SONDAK et al., 2017). On the food web dynamic, $11.1 \%$ of the articles discussed mainly about the influence and importance of the seaweed in the interaction with the organisms that are part of the marine ecosystem (MCDERMID et al., 2015; OSTMAN et al., 2016; HASSELSTRÖM et al., 2018).

Cultural services are presented by $13.5 \%$ of the studies analyzed (mentioned 39 times). Of these services, the employment and income generation through traditional activities were identified in $46.2 \%$ of the literature. These studies highlighted the activities that result from seaweed harvesting in natural beds, small cultivations and pilot projects carried out in developing countries (REBOURS et al., 2014; HAYASHI et al., 2014; O'CONNELL-MILNE et al., 2015; KITOLELEI et al., 2016; ZUNIGA-JARA et al., 2016; MARINHOSORIANO, 2017).

Science and education were the second most addressed service, representing $25.6 \%$ of the studies and highlighting the interest and scientific growth associated with seaweed (HASSELSTRÖM et al., 2018). The studies that examined the service of cultural heritage (15.4\%) emphasized the participation of women in harvesting and cultivating seaweed as well as the importance of empirical knowledge and management skills, which are transmitted from generation to generation by traditional communities (REBOURS et al., 2014; O'CONNELL-MILNE et al., 2015; KITOLELEI et al., 2016; MARINHO-SORIANO, 2017; THURSTAN et al., 2018).

Recreation services were cited in $12.8 \%$ of the articles. Of these, the research carried out by Hussin et al. (2015) analyzed touristic potential based on the visitation of seaweed farming in Malaysia and its contribution to the development of local tourism.

Figure 4 shows the word cloud generated based on the results of the bibliographic research. A total 
of 467 words were identified, grouped and organized graphically. The size of each word was determined by how frequently it appeared, allowing quick identification of the key words with emphasis on the main ecosystem services of each category.

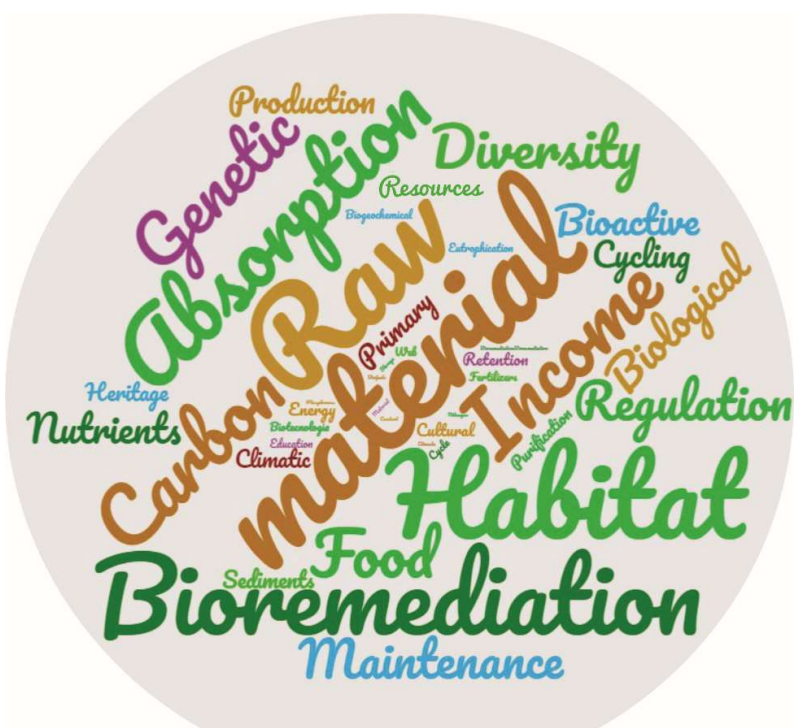

Figure 4: Word cloud generated from the main ecosystem services associated with seaweeds in the literature.

The word cloud highlighted that the most frequent words associated with seaweed were providers of goods and services for human consumption (raw material (53), food (14) and bioactive compounds (10)) and helpers in ecosystem regulation (bioremediation (26), absorption (19), regulation (14), sediments (6) and retention (6)). Also identified as frequent words were those associated with the support that seaweeds provide as habitat and maintain biological diversity (habitat (27), biological (19), maintenance (14) and genetics (07)), in addition to providing services related to social and cultural development (income (18), heritage (6), education (6), cultural (6) and science (6)).

\section{Ecosystem services provided through the cultivation of Gracilaria birdiae (Northeast, Brazil)}

Seaweed farming of Gracilaria species is an industry that is well established in many parts of the world. In tropical regions, this activity is a business option in the production sector that can contribute to the economic and social development of coastal populations, especially of women, who can earn an income for themselves and their families (MARINHO-SORIANO, 2017). In general, cultivation in tropical countries makes use of relatively simple technology (vegetative reproduction), requiring little education and minimal initial investment. Additionally, considering that the production of species cultivated allows shorter cycles ( 2 months), it can bring a faster financial return on the investment.

Seaweed cultivation in the Northeast region of Brazil is carried out by a small association composed almost exclusively of women. A long, narrow reef containing several species of seaweeds is close to the cultivation implanted at Rio do Fogo beach, a traditional fishing village. Many extractive activities are developed in the region, including artisanal fishing and seaweed harvesting. The seaweed cultivated belongs to the genus Gracilaria and its harvesting in the intertidal zone was considered an important source of income 
for coastal communities for a long time (REBOURS et al., 2014).

The cultivation of Gracilaria offers several ecosystem services even on a small scale (subsistence). The research on these services identified 12 services, five of which pertained to the support category (41\%), followed by three to cultural (25\%), two to provision (17\%) and two to regulation (17\%) (Table 2, Figure 5).

Table 2: Identification and classification of ecosystem services in the cultivation of seaweed Gracilaria birdiae in Northeast Region of Brazil (Rio do Fogo beach).

\begin{tabular}{|c|c|c|c|}
\hline Classification & Ecosystem Services & Use and Benefits & Benefited Actors \\
\hline Support & $\begin{array}{l}\text { Biodiversity } \\
\text { Habitat } \\
\text { Maintenance of biological } \\
\text { and genetic diversity } \\
\text { Food web dynamic } \\
\text { Primary production }\end{array}$ & $\begin{array}{l}\text { The habitat contributes to the conservation and } \\
\text { maintenance of the biological, genetic and evolutionary } \\
\text { diversity }\end{array}$ & $\begin{array}{l}\text { Local and } \\
\text { community }\end{array}$ \\
\hline Cultural & $\begin{array}{l}\text { Science and education } \\
\text { Cultural heritage } \\
\text { Income generation }\end{array}$ & $\begin{array}{l}\text { Provides essential functions for maintenance of human } \\
\text { life }\end{array}$ & $\begin{array}{l}\text { Local community and } \\
\text { local commerce }\end{array}$ \\
\hline Provision & $\begin{array}{l}\text { Raw material for industries } \\
\text { Food production }\end{array}$ & Provides goods and services for human consumption & $\begin{array}{l}\text { Local and } \\
\text { community }\end{array}$ \\
\hline Regulation & $\begin{array}{l}\text { Climate regulation } \\
\text { Bioremediation }\end{array}$ & $\begin{array}{l}\text { Support for life and other biological processes, } \\
\text { maintenance and balance of the marine ecosystem }\end{array}$ & Local community \\
\hline
\end{tabular}

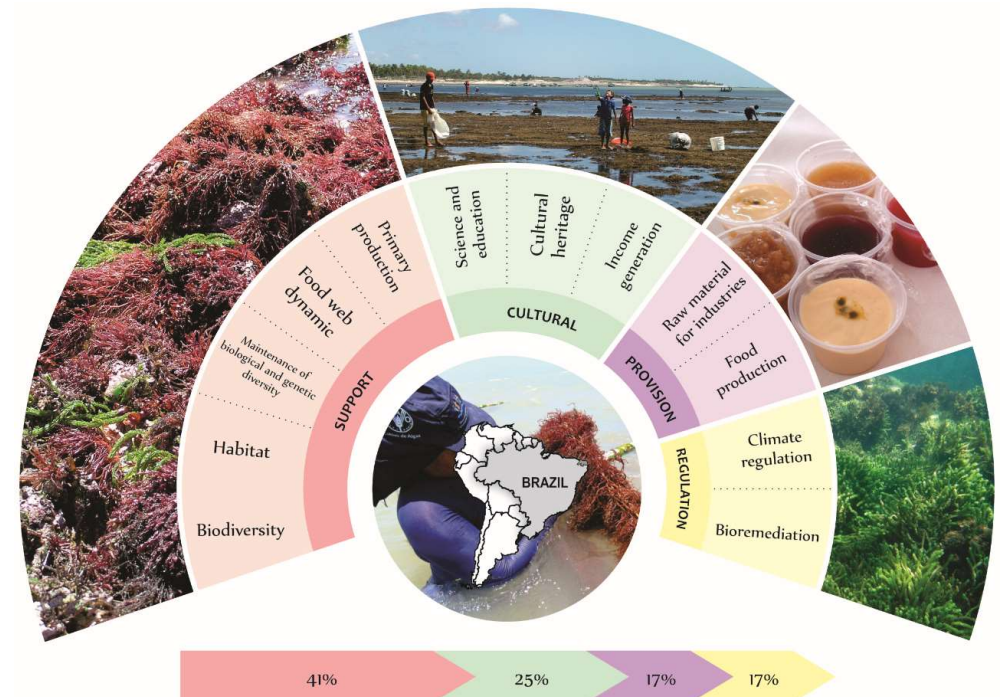

Figure 5: Ecosystem services provided by seaweeds.

Regarding supporting services, the structures of Gracilaria cultivation attract larvae and juveniles of several species of commercially important fishes (Mycteroperca bonaci, Epinephelus spp.) and crustaceans, such as shrimps (Litopenaeus schmitti, Farfantepenaeus subtilis and Farfantepenaeus brasiliensis), crab (Callinectes sapidus) and lobster (Panulirus argus). Furthermore, transient species, such as turtles (Chelonia mydas) and sea hares (Aplysia spp.), are common in the cultivation surroundings. These animals use the area as feeding grounds and/or shelter. From an ecological point of view, the biodiversity associated with Gracilaria beds and cultivation promotes interaction between species and increases the food potential of a considerable number of vertebrates and invertebrates. For example, epiphytes and biofilms that grow over seaweed are an essential source of food for herbivores and detritivores.

Seaweeds also provide surface for settlement for numerous species of epiphytes and epifauna due to their structural complexity. On the other hand, it is worth emphasizing the importance of G. birdiae as a 
primary product, serving as an important link in the trophic chain and supporting biodiversity.

The provisioning services offered by seaweed cultivation present several potential uses in different sectors, such as food, animal feed, chemical compounds, ornamental resources, among others (CHUNG et al., 2017; HASSELSTRÖM et al., 2018). The services provided by Gracilaria cultivation are directly related to biomass production as well as its use for extraction of phycocolloids and bioactive compounds for the cosmetic industry. On a smaller scale, the Association of Seaweed Farming (AMAR) also uses biomass to make value-added products for immediate use, such as cakes, cookies and desserts (mousse, jelly, etc.).

The benefits acquired through both cultivation and regulating services are associated with carbon sequestration and the removal of nutrients from water, especially nitrogen $(N)$ and phosphorus $(P)$ from terrestrial sources (leaching). $\mathrm{CO}_{2}$ absorption and assimilation are directly related to the process of photosynthesis (DUARTE et al., 2017), which is closely linked to biomass production, which, in turn, has a positive impact in the control of seawater acidification (DUARTE et al., 2017; KRAUSE-JENSEN et al., 2016). Another important consideration concerning photosynthesis is the production of oxygen by seaweed and the consequent improvement in water quality. On another note, Gracilaria species are known for their potential as biofilters (MARINHO-SORIANO et al., 2009a), thus, for their ability to remove $\mathrm{N}$ and $\mathrm{P}$ from water and accumulate these elements in its tissue, playing an important role in mitigating eutrophication. The bioremediation of these nutrients is of special interest for the study area, because domestic sewage is discharged without treatment. Since cultivation can minimize the effects of eutrophication caused by runoff of used water directly to the sea, an increase in the cultivation area can bring important benefits to public health on a local scale.

Seaweed harvesting from natural beds is an activity linked to the identity of coastal communities, mainly in the Northeast region of Brazil. The harvest of these organisms for the phycocolloid industry (agar and carrageenan) is an activity that has been going since the 60s (MARINHO-SORIANO, 2017). This cultural heritage is a rich source of traditional knowledge, passed from generation to generation, father to son, which is within the economic, social and cultural structure of the community. The importance of seaweed in the lives of most of the coastal community reflects its relevance in the cultural life of these communities. Thus, the presence of algal species, especially the genus Gracilaria, may be considered a cultural service linked to the symbolic value of heritage species.

The cultivation of $G$. birdiae is seen as a potential source of employment and income in the coastal areas of Brazilian Northeast. This activity requires a low level of technology and investment and can be undertaken as a family activity. It has little environmental impact and is normally compatible with traditional fishing activities and other subsistence uses of the coastal marine environment (MARINHO-SORIANO, 2017). Cultivation also stimulates cognitive development, including education and research. The activity of scientific research, according to the literature, is mainly focused on studies of biomass production, ecophysiology and the development of cultivation techniques (BEZERRA et al., 2010; FERNANDES et al., 2017), whereas education is more linked with knowledge of the species cultivated and cultivation technologies.

The results presented here show that Gracilaria cultivation provides several ecosystem services in 
addition to those initially associated with biomass production, such as the supply of raw materials and the economic benefits of the activity. In practice, the cultivation of Gracilaria plays a vital economic, ecological and cultural role, providing subsistence and reducing poverty.

As shown, seaweeds have great potential to contribute with different solutions for a more sustainable world. They have been playing an important role in the history of human use of coastal resources and in the functioning of marine ecosystems. Seaweeds can also help developing countries to achieve the goals associated with sustainable development objectives (Figure 6). In this sense, seaweed-related activities (harvest and cultivation) are aligned with several of the goal of the Sustainable Development Goals. These include goal 2 (Zero Hunger): they contribute with food for man, animals and fertilizers for agriculture; goal 3 (Health and Well-being): seaweed offer several applications in medicine, biotechnology and use as nutraceuticals; goal 5: (Gender Equality) engagement of women in different activities, such as harvesting, preparing seedlings, structures for cultivation, processing, drying and marketing; goal 8 (Economic Growth): seaweeds are a source of income, especially for the most vulnerable people; goal 10 (Reducing Inequality): seaweeds support the economy of coastal populations, especially in the tropics, reducing social inequalities; goal 12 (Responsible Consumption and Production): potential use of seaweed extracts in the biodegradable bioplastic sector - transition from petrochemicals to green chemistry; goal 13: (Climate Action) the production of seaweed for food and animal feed can reduce the pressure for land use. They can also mitigate the processes of eutrophication, ocean acidification and carbon sequestration; and goal 14 (Life Below Water): seaweeds support the marine ecosystem, providing habitat, food, shelter, in addition to contributing to the conservation of biodiversity.

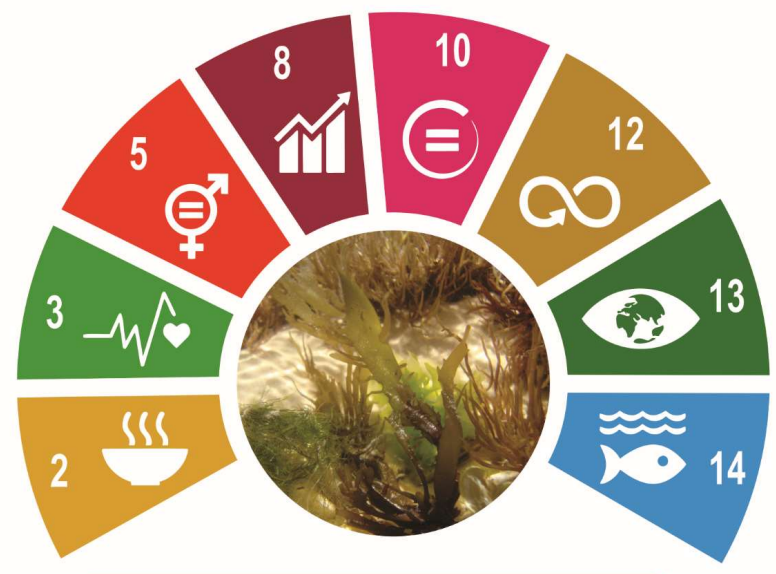

SUSTAINABLE DEVELOPMENT GOALS

Figure 6: Seaweed support for the Sustainable Development Goals.

\section{CONCLUSIONS}

Based on the results obtained through bibliographic research, it was possible to identify the ecosystem services provided by seaweed natural beds as well as the benefits associated with the cultivation of these organisms in several regions of the world. Seaweeds are considered valuable sources of ecosystem services and their uses were described in four categories (regulation, provision, support and cultural). Of these services, we emphasize the use of seaweed in bioremediation, acting as a biological filter and essential 
for the maintenance and balance of the ecosystems. Furthermore, seaweeds serve as raw material for food supply and various industrial uses and provide habitat for diverse species, guaranteeing the maintenance of biological and genetic diversity of associated organisms. Seaweed-based activities are also recognized as a responsible mean of generating employment and income in coastal regions.

Concerning the services linked to Gracilaria cultivation, we highlight the role of seaweed in providing cultural and economic benefits to the community, strengthening services in coastal areas by adding value to these activities.

ACKNOWLEDGMENTS: This study was financed in part by the Coordenação de Aperfeiçoamento de Pessoal de Nível Superior - Brasil (CAPES) - Finance Code 001.

\section{REFERENCES}

ARINA, N.; RAYNUSHA, C.; HIDAYAH, N.; ZAINEE, N. F. A.; PRATHEP, A.; ROZAIMI, M.. Coralline contribution to ecological services of carbon storage in a disturbed seagrass meadow. Marine Environmental Research, v.162, p.105156, 2020. DOI:

https://doi.org/10.1016/j.marenvres.2020.105156

ASMAWATI, A.; HASYIM, R.; LIANINGSIH, A.; ARIANI, D.. The difference of anti-inflammatory effect of brown algae extract Panida sp. and Sargassum sp. that is derived from Punaga beach, South Sulawesi. Journal of Dentomaxillofacial Science, v.1, p.116-119, 2016. DoI:

https://doi.org/10.15562/jdmfs.v1i2.8

AUGYTE, S.; YARISH, C.; REDMOND, S.; KIM, J. K.. Cultivation of a orphologically distinct strain of the sugar kelp, Saccharina latissima form angustissima, forma coastal Maine, USA, with implications for ecosystem services. Journal of Applied Phycology, v.29, n.4, p.19671976, 2017. DOI: https://doi.org/10.1007/s10811-017-1102$\underline{x}$

BEZERRA, A. F.; MARINHO-SORIANO, E.. Cultivation of the red seaweed Gracilaria birdiae (Gracilariales, Rhodophyta) in tropical waters of northeast Brazil. Biomass \& Bioenergy, v.34, n.12, p.1813-1817, 2010. DOI:

https://doi.org/10.1016/j.biombioe.2010.07.016

BUSCHMANN, A. H.; CAMUS, C.; INFANTE, J.; NEORI, A.; ISRAEL, Á.; HERNÁNDEZ-GONZÁLEZ, M. C.; PEREDA, S. V.; GOMEZ-PINCHETTI, J. L.; GOLBERG, A.; TADMOR-SHALEV, N.; CRITCHLEY, A. T.. Seaweed production: overview of the global state of exploitation, farming and emerging research activity. European Journal of Phycology, v.52, n.4, p.391406, 2017. DOI:

https://doi.org/10.1080/09670262.2017.1365175

CALLAWAY, R.; SHINN, A. P.; GRENFELL, S. E.; BRON, J.E.; BURNELL, G.; COOK, E. J.; CRUMLISH, M.; CULLOTY, S.; DAVIDSON, K.; ELLIS, R. P.; FLYNN, K. J.; FOX, C.; GREEN, D. M.; HAYS, G. C.; HUGHES, A. D.; JOHNSTON, J.; LOWE, C. D.; LUPATSCH I.; MALHAM, S.; MENDZIL, A. F.; NICKELL, T.; PICKERELL, T.; ROWLE, A. F.; STANLEY, M. S.; TOCHER, D. R.; TURNBULL, J. F.; WEBB, G.; WOOTTON, E.; SHIELDS, R. J.. Review of climate change impacts on marine aquaculture in the UK and Ireland. Aquatic Conservation, v.22, n.3, p.389-

\section{1, 2012. DOI: https://doi.org/10.1002/aqc.2247}

CHUNG, I. K.; BEARDALL, J.; MEHTA, S.; SAHOO, D.; STOJKOVIC, S.. Using marine for carbon sequestration: a critical appraisal. Journal of Applied Phycology, v.23, n.5, p.877-886, 2011. DOI: https://doi.org/10.1007/s10811-010$\underline{9604-9}$

CHUNG, I. K.; OAK, J. H.; LEE, J. A.; SHIN, J. A.; KIM, J. G.; PARK, K. S.. Installing kelp forests/seaweed beds for mitigation and adaptation against global warming: Korean Project Overview. ICES Journal of Marine Science, v.70, n.5, p.1038-1044, 2013. DOI: https://doi.org/10.1093/icesjms/fss206

CHUNG, I. K.; SONDAK, C. F.; BEARDALL, J.. The future of seaweed aquaculture in a rapidly changing world. European Journal of Phycology, v.52, n.4, p.495-505, 2017. DOI: https://doi.org/10.1080/09670262.2017.1359678

DELANEY, A.; FRANGOUDES, K.; LI, S. A.. Society and seaweed: Understanding the past and present. In: FLEURENCE, J.; LEVINE, I.. Seaweed in health and disease prevention. Cambridge: Academic Press, 2016. p.7-40. DOI: https://doi.org/10.1016/B978-0-12-802772-1.00002-6

DUARTE, C. M.; WU, J.; XIAO, X.; BRUHN, A.; KRAUSEJENSEN, D.. Can seaweed farming play a role in climate change mitigation and adaptation? Frontiers in Marine Science, v.4, p.100, 2017. DOI: https://doi.org/10.3389/fmars.2017.00100

FASAHATI, P.; WOO, H. C.; LIU, J. J.. Industrial-scale bioethanol production from brown algae: effects of pretreatment processes on plant economics. Applied Energy, v.139, p.175-187, 2015. Dol: https://doi.org/10.1016/j.apenergy.2014.11.032

FERNANDES, F.; OLIVEIRA, S. R.; KLEIN, V.; CARNEIRO, M. A. A.; COLEPICOLO, P.; MARINHO-SORIANO, E.. Effect of fertilization pulses on the production of Gracilaria birdiae seedlings under laboratory and field conditions. Journal of Applied Phycology, v.29, n.2, p.695-705, 2017. DOI: https://doi.org/10.1007/s10811-016-0994-1

GAILLANDE, C.; PAYRI, C.; REMOISSENET, G.; ZUBIA, M.. 
Caulerpa consumption, nutritional value and farming in the Indo-Pacific region. Journal of Applied Phycology, v.29, n.5, p.2249-2266, 2017. DOI: https://doi.org/10.1007/s10811$\underline{016-0912-6}$

GAO, X.; ENDO, H.; AGATSUMA, Y.. Seasonal changes in photosynthesis, growth, nitrogen accumulation, and salinity tolerance of Chaetomorpha crassa (Cladophorales, Chlorophyceae). Journal of Applied Phycology, v.30, n.3, p.1905-1912, 2018. DOI: https://doi.org/10.1007/s10811$\underline{017-1381-2}$

GENTRY, R. R.; ALLEWAY, H. K.; BISHOP, M. J.; GILLIES, C. L.; WATERS, T.; JONES, R.. Exploring the potential for marine aquaculture to contribute to ecosystem services. Reviews Aquaculture, v.12, p.499-512, 2020. DOI: https://doi.org/10.1111/raq.12328

GOH, C. S.; LEE, K. T. A.. Visionary and conceptual -based third-generation bioethanol (TGB) biorefinery in Sabah, Malaysia as an underlay for renewable and sustainable development. Renewable and Sustainable Energy Reviews, v.14, n.2, p.842-848, 2010. DOI: https://doi.org/10.1016/j.rser.2009.10.001

GROOT, R. S.; FISHER, B.; CHRISTIE, M.; ARONSON, J.; BRAAT, L.; HAINES-YOUNG, R.; GOWDY, J.; MALTBY, E.; NEUVILLE, A.; POLASKY, S.; PORTELA, R.; RING, I.. Integrating the ecological and economic dimensions in biodiversity and ecosystem service valuation. In: KUMAR, P.. The Economics of Ecosystems and Biodiversity: Ecological and Economic Foundations. London: Earthscan, 2010. p.1-40.

GROOT, R. S.; WILSON, M. A.; BOUMANS, R. M. J.. A typology for the classification, description and valuation of ecosystem functions, goods and services. Ecological Economics, v.41, n.3, p.393-408, 2002. DOI: https://doi.org/10.1016/S09218009(02)00089-7

HALPERN, B. S.; LONGO, C.; HARDY, D.; MCLEOD, K. L.; SAMHOURI, J. F.; KATONA, S. K; KLEISNER, K.; LESTER, S. E.; O'LEARY, J.; RANELLETTI, M.; ROSENBERG, A. A.; SCARBOROUGH, C.; SELIG, E.R.; BEST, B. D.; BRUMBAUGH, D. R.; CHAPIN, F. S.; CROWDER, L. B.; DALY, K. L.; DONEY, S. C.; ELFES, C.; FOGARTY, M. J.; GAINES, S. D.; JACOBSEN, K. I.; KARRER, L. B.; LESLIE, H. M.; NEELEY, E.; PAULY, D.; POLASKY, S.; RIS, B.; MARTIN, K. S.; STONE, G. S.; SUMAILA, U. R.; ZELLER, D.. An index to assess the health and benefits of the global ocean. Nature, v.488, p.615-622, 2012. DOI: https://doi.org/10.1038/nature11397

HAN, T.; JIANG, Z.; FANG, J.; ZHANG, J.; MAO, Y.; ZOU, J.; HUANG, Y.; WANG, D.. Carbon dioxide fixation by the seaweed Gracilaria lemaneiformis in integrated multitrophic aquaculture with the scallop Chlamys farreri in Sanggou Bay, China. Aquaculture International, v.21, n.5, p.1035-1043, 2013. DOI: https://doi.org/10.1007/s10499$\underline{012-9610-9}$

HASSELSTRÖM, L.; VISCH, W.; GRÖNDAHL, F.; GÖRAN, M.; NYLUND, G. M.; PAVIA, H.. The impact of seaweed cultivation on ecosystem services - a case study from the west coast of Sweden.Marine Pollution Bulletin, v.133, p.5364, 2018. DOI:

https://doi.org/10.1016/i.marpolbul.2018.05.005

HAYASHI, L.; BULBOA, C.; KRADOLFER, P.; SORIANO, G.;
ROBLEDO, D.. Cultivation of red seaweeds: a Latin American perspective. Journal of Applied Phycology, v.26, n.2, p.719727, 2014. DOI: https://doi.org/10.1007/s10811-013-0143-z

HUSSIN, R.; YASIR, S. M.; KUNJURAMAN, V.. Potential of seaweed cultivation as a community-based rural tourism product: a stakeholders' perspectives. Advances in Environmental Biology, v.9, n.5, p.154-156, 2015.

KANG, Y. H.; KIM, S.; LEE, J. B.; CHUNG, I. K.; PARK, S. R. Nitrogen biofiltration capacities and photosynthetic activity of Pyropia yezoensis Ueda (Bangiales, Rhodophyta): groundwork to validate its potential in integrated multitrophic aquaculture (IMTA). Journal of Applied Phycology, v.26, n.2, p.947-955, 2014. DOI:

https://doi.org/10.1007/s10811-013-0214-1

KIM, J. K.; YARISH, C.; HWANG, E. K.; PARK, M.; KIM, Y.. Seaweed aquaculture: cultivation technologies, challenges and its ecosystem services. Algae, v.32, n.1, p.1-13, 2017. DOI: https://doi.org/10.4490/algae.2017.32.3.3

KITOLELEI, J. V.; SATO, T.. Analysis of perceptions and knowledge in managing coastal resources: A case study in Fiji. Frontiers in Marine Science, v.3, p.189, 2016. DOI: https://doi.org/10.3389/fmars.2016.00189

KRAUSE-JENSEN, D.; DUARTE, C. M.. Substantial role of in marine carbon sequestration. Nature Geoscience, v.9, n.10, p.737-743, 2016. DOI: https://doi.org/10.1038/NGEO2790

MANTRI, V. A.; ESWARAN, K.; SHANMUGAM, M.; GANESAN, M.; VEERAGURUNATHAN, M.; THIRUPPATHI, S.; REDDY, C. R. K.; SETH, A.. An appraisal on commercial farming of Kappaphycus alvarezii in India: success in diversification of livelihood and prospects. Journal of Applied Phycology, v.29, n.1, p.335-357, 2017. DOI: https://doi.org/10.1007/s10811-016-0948-7

MARINHO-SORIANO, E.. Estudos sobre macroalgas marinhas. In: CHELLAPA, S.; MARINHO-SORIANO, E.; CÂMARA, M. R.; AMADO, A. M.. Ciências aquáticas: 50 anos de pesquisa no Rio Grande do Norte. Natal: EDUFRN, 2013. p.61-78.

MARINHO-SORIANO, E.. Historical context of commercial exploitation of seaweeds in Brazil. Journal of Applied Phycology, v.29, n.2, p.665-671, 2017. DOI: https://doi.org/10.1007/s10811-016-0866-8

MARINHO-SORIANO, E.; NUNES, S. O.; CARNEIRO, M. A. A.; PEREIRA, D. C.. Nutrients' removal from aquaculture wastewater using the Gracilaria birdiae. Biomass \& Bioenergy, v.33, n.2, p.327-331, 2009a. DOI: https://doi.org/10.1016/j.biombioe.2008.07.002

MARINHO-SORIANO, E.; PANUCCI, R. A.; CARNEIRO, M. A. A.; PEREIRA, D. C.. Evaluation of Gracilaria caudata J. Agardh for bioremediation of nutrients from shrimp farming wastewater. Bioresource Technology, v.100, n.24, p.61926198, 2009b. DOI: https://doi.org/10.1016/j.biortech.2009.06.102

MARTINS, A. P.; YOKOYA, N. S.; COLEPICOLO, P.. Biochemical modulation by carbon and nitrogen addition in cultures of Dictyota menstrualis (Dictyotales, Phaeophyceae) to generate oil-based bioproducts. Marine Biotechnology, v.18, n.3, p.314-326, 2016. DOI: 
https://doi.org/10.1007/s10126-016-9693-9

MCDERMID, K. J.; LEFEBVRE, J. A.; BALAZS, G. H.. Nonnative seashore paspalum, Paspalum vaginatum (Poaceae), consumed by Hawaiian green sea turtles (Chelonia mydas): Evidence for nutritional benefits. Pacific Science, v.69, n.1, p.48-58, 2015. DOI: https://doi.org/10.2984/69.1.3

MONGIN, M.; BAIRD, M. E.; HADLEY, S.; LENTON, A.. Optimising reef-scale $\mathrm{CO}_{2}$ removal by seaweed to buffer ocean acidification. Environmental Research Letters, v.11, n.3, p.1-10, 2016. DOI: https://doi.org/10.1088/1748$\underline{9326 / 11 / 3 / 034023}$

NARDELLI, A. E.; CHIOZZINI, V. G.; BRAGA, E. S.; CHOW, F.. Integrated multi-trophic farming system between the green seaweed Ulva lactuca, mussel, and fish: a production and bioremediation solution. Journal of Applied Phycology, v.31, n.2, p.847-856, 2019. DOI: https://doi.org/10.1007/s10811018-1581-4

O'CONNELL-MILNE, S. A.; HEPBURN, C. D.. A harvest method informed by traditional knowledge maximises yield and regeneration post-harvest for karengo (Bangiaceae). Journal of Applied Phycology, v.27, n.1, p.447-454, 2015. DOI: https://doi.org/10.1007/s10811-014-0318-2

OSTMAN, O.; EKLOF, J.; ERIKSSON, B. K.; OLSSON, J.; MOKSNES, P. O.; BERGSTRÖM, U.. Top-down control as important as nutrient enrichment for eutrophication effects in North Atlantic coastal ecosystems. Journal of Applied Ecology, v.53, n.4, p.1138-1147, 2016. DOI: https://doi.org/10.1111/1365-2664.12654

PEREIRA, L.; CRITCHLEY, A. T.; AMADO, A. M.; RIBEIROCLARO, P. J. A.. A comparative analysis of phycocolloids produced by underutilized versus industrially utilized carrageenophytes (Gigartinales, Rhodophyta). Journal of Applied Phycology, v.21, n.5, p.599-605, 2009. DOI: https://doi.org/10.1007/s10811-009-9447-4

REBOURS, C.; MARINHO-SORIANO, E.; ZERTUCHEGONZÁLEZ, J. A.; HAYASHI, L.; VÁSQUEZ, J. A.; KRADOLFER, P.; SORIANO, G.; UGARTE, R.; ABREU, M. H.; BAY-LARSEN, I.; HOVELSRUD, G.; RØDVEN, R.; ROBLEDO, D.. Seaweeds: opportunity for wealth and sustainable livelihood for coastal communities. Journal of Applied Phycology, v.26, n.5, p.1939-1951, 2014. DOI: https://doi.org/10.1007/s10811014-0304-8

ROBERTS, D. A.; PAUL, N. A.; DWORJANYN, S. A.; BIRD, M. I.; NYS, R.. Biochar from commercially cultivated seaweed for soil amelioration. Scientific Reports, v.5, p.1-6, 2015. DOI: https://doi.org/10.1038/srep09665

SFRISO, A.; MISTRI, M.; MUNARI, C.; BUOSI, A.; SFRISO, A. A. Management and Exploitation of Macroalgal Biomass as a Tool for the Recovery of Transitional Water Systems. Frontiers in Ecology and Evolution, v.8, 2020. DOI: https://doi.org/10.3389/fevo.2020.00020

SMALE, D. A.; BURROWS, M. T.; MOORE, P.; O'CONNOR, N.;
HAWKINS, S. J.. Threats and knowledge gaps for ecosystem services provided by kelp forests: a northeast Atlantic perspective. Ecology Evolution, v.3, n.11, p.4016-4038, 2013. DOI: https://doi.org/10.1002/ece3.774

SOARES, R. H. R. M.; ASSUNÇÃO, C. A.; FERNANDES, F. O.; MARINHO-SORIANO, E.. Identification and analysis of ecosystem services associated with biodiversity of saltworks. Ocean \& Coastal Management, v.163, p.278-284, 2018. DOI:

https://doi.org/10.1016/j.ocecoaman.2018.07.007

SONDAK, C. F. A.; ANG JUNIOR, P. O.; BEARDALL, J.; BELLGROVE, A.; BOO, S. M.; GERUNG, G. S.; HEPBURN, C. D.; HONG, D. D.; HU, Z. KAWAI, H.; LARGO, D.; LEE, J. A.; LIM, P.E.; MAYAKUN, J.; NELSON, W. A.; OAK, J. H.; PHANG, S.-M.; SAHOO, D.; PEERAPORNPIS, Y.; YANG, Y.; CHUNG, I. K.. Carbon dioxide mitigation potential of seaweed aquaculture beds (SABs). Journal of Applied Phycology, v.29, n.5, p.23632373, 2017. DOI: https://doi.org/10.1007/s10811-016-10221

STÉVANT, P.; REBOURS, C.; CHAPMAN, A.. Seaweed aquaculture in Norway: recent industrial developments and future perspectives. Aquaculture International, v.25, n.4, p.1373-1390, 2017. DOI: https://doi.org/10.1007/s10499$\underline{017-0120-7}$

SUNDAY, J. M.; BATES, A. E.; DULVY, N. K.. Thermal tolerance and the global redistribution of animals. Nature Climate Change, v.2, n.9, p.686-690, 2012. DOI: https://doi.org/10.1038/nclimate1539

THOMPSON, R. C.; CROWE, T. P.; HAWKINS, S. J.. Rocky intertidal communities: past environmental changes, present status and predictions for the next 25 years. Environmental Conservation, v.29, n.2, p.168-191, 2002. DOI: https://doi.org/10.1017/S0376892902000115

THURSTAN, R. H.; BRITTAIN, Z.; JONES, D. S.; CAMERON, E.; DEARNALEY, J.; BELLGROVE, A.. Aboriginal uses of seaweeds in temperate Australia: an archival assessment. Journal of Applied Phycology, v.30, n.3, p.1821-1832, 2018. DOI: https://doi.org/10.1007/s10811-017-1384-z

TROELL, M.; PIHL, L.; RÖNNBÄCK, P.; WENNHAGE, H.; SÖDERQVIST, T.; KAUTSKY, N.. Regime shifts and ecosystem services in Swedish coastal soft bottom habitats: when resilience is undesirable. Ecology and Society, v.10, n.1, p.113, 2005.

WU, H.; SHIN, K. S.; JANG, S.; YARISH C.; KIM J. K.. Growth and nutrient bioextraction of Gracilaria chorda, $G$. vermiculophylla, Ulva prolifera, and $U$. compressa under hypo-and hyper-osmotic conditions. Algae, v.33, n.4, p.329340, 2018. DOI: https://doi.org/10.4490/algae.2018.33.11.13

ZUNIGA-JARA, S.; MARIN-RIFFO, M.. Bioeconomic analysis of small-scale cultures of Kappaphycus alvarezii (Doty) Doty in India. Journal of Applied Phycology, v.28, n.2, p.1133-1143, 2016. DOI: https://doi.org/10.1007/s10811-015-0616-3

A CBPC - Companhia Brasileira de Produção Científica (CNPJ: 11.221.422/0001-03) detém os direitos materiais desta publicação. Os direitos referem-se à publicação do trabalho em qualquer parte do mundo, incluindo os direitos às renovações, expansões e disseminações da contribuição, bem como outros direitos subsidiários. Todos os trabalhos publicados eletronicamente poderão posteriormente ser publicados em coletâneas impressas sob coordenação da Sustenere Publishing, da Companhia Brasileira de Produção Científica e seus parceiros autorizados. Os (as) autores (as) preservam os direitos autorais, mas não têm permissão para a publicação da contribuição em outro meio, impresso ou digital, em português ou em tradução. 